African Crop Science Journal by African Crop Science Society is licensed under a Creative Commons Attribution 3.0 Uganda License. Based on a work at www.ajol.info/ and www.bioline.org.br/cs DOI: https://dx.doi.org/10.4314/acsj.v29i2.6

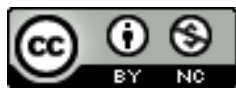

\title{
LEVERAGING EARLY DRY SEASON PLANTING OF GINGER UNDER IRRIGATION TO ENHANCE PRODUCTION FROM BACTERIAL WILT INFECTED SEED RHIZOME
}

\author{
ASFAW KIFLE and DERBEW BELEW ${ }^{1}$ \\ Southern Agricultural Research Institute, Areka Agricultural Research Center, \\ Department of Horticulture, Areka, Ethiopia \\ ${ }^{1}$ Jima University, College of Agriculture and Veterinary Medicine, Department of Horticulture \\ and Plant Sciences, Jimma, Ethiopia \\ Corresponding author: akifle2003@gmail.com
}

(Received 24 October 2020; accepted 9 April 2021)

\begin{abstract}
Ginger (Zingiber officinale Rosc.), one of the important export crops grown in Ethiopia for its underground aromatic rhizome, is threatened by the destructive Ginger Bacterial Wilt (GBW) disease. The objective of this study was to evaluate the effect of moisture sources, plant spacing, and nitrogen fertiliser, on rhizome yield and yield attributes of latently infected ginger seed rhizomes. Treatments included two levels of moisture sources (irrigation and rainfall), two levels of plant spacing $(40 \mathrm{~cm} \mathrm{x}$ $15 \mathrm{~cm}$ and $40 \mathrm{~cm} \times 30 \mathrm{~cm}$ ), and three rates of nitrogen fertiliser, i.e., 0,46 and $92 \mathrm{~kg} \mathrm{~N} \mathrm{ha}^{1}$ applied in the form of urea. Analysis of variance showed significant $(\mathrm{P}<0.01)$ variations between moisture sources and planting space for fresh rhizome yield, but not for $\mathrm{N}$ levels. Moisture sources also significantly $(\mathrm{P}<0.01)$ affected stand count at harvest, and other yield attributes, viz., number of buds per rhizome per hill, number of rhizomes per plant, rhizome size and rhizome and propagule weight. Planting infected ginger rhizomes early in dry season, with irrigation, led to production of healthy and large rhizomes weighing up to $662 \mathrm{~g}$. Narrow plant spacing showed better yield performance and yield attributes, as opposed to wide spacing; though wide plant spacing was more preferred for management of Ginger Bacterial Wilt during humid and warm weather conditions. This experiment clearly demonstrated that planting ginger rhizomes, which are latently infected with Ralistonia solanacearum early in dry season, using irrigation could be the best option to propagate disease free rhizomes since dry condition successfully restrains bacterial development, disintegrating the pathosystem. i.e., avoiding high humidity, which is one of the ideal conditions for bacterial growth. Early planting in dry season, using irrigation is a cost effective and easily applicable practice to control Ginger Bacterial Wilt disease.
\end{abstract}

Key Words: Early dry planting, irrigation, Zingiber officinale 


\section{RÉSUMÉ}

Le gingembre (Zingiber officinale Rosc.), est l'une des principales cultures d'exportation cultivées en Éthiopie pour son rhizome aromatique souterrain, et il est menacé par la maladie destructrice de la flétrissure bactérienne du gingembre (GBW). L'objectif de cette étude était d'évaluer l'effet des sources d'humidité, des espaces de plantation et des engrais azotés sur le rendement des rhizomes et les attributs de rendement des rhizomes de graines de gingembre infectés de façon latente. Les traitements comprenaient deux niveaux de sources d'humidité (irrigation et pluviométrie), deux niveaux d'espaces de plantation $\left(40 \mathrm{~cm} \times 15 \mathrm{~cm}\right.$ et $40 \mathrm{~cm} \times 30 \mathrm{~cm}$ ) et trois taux d'engrais azoté, soit 0,46 et $92 \mathrm{~kg} \mathrm{~N}^{-1}$ appliqué sous forme d'urée. L'analyse de la variance a montré des variations significatives $(\mathrm{P}<0,01)$ entre les sources d'humidité et l'espace de plantation pour le rendement des rhizomes frais, mais pas pour les niveaux d'azote. Les sources d'humidité ont également affecté de manière significative (P $<0,01$ ) le nombre de peuplements à la récolte et d'autres attributs de rendement, à savoir le nombre de bourgeons par rhizome par colline, le nombre de rhizomes par plante, la taille des rhizomes et le rhizome et le poids des propagules. La plantation de rhizomes de gingembre infectés au début de la saison sèche, avec irrigation, a conduit à la production de rhizomes sains et de grande taille pesant jusqu'à $662 \mathrm{~g}$. Un espacement étroit des plantes a montré une meilleure performance de rendement et des attributs de rendement, par opposition à un espacement large; bien qu'un espacement large entre les plantes soit préférable pour la gestion de la flétrissure bactérienne du gingembre dans des conditions météorologiques humides et chaudes. Cette expérience a clairement démontré que la plantation de rhizomes de gingembre qui sont infectés de manière latente par Ralistonia solanacearum au début de la saison sèche en utilisant l'irrigation pourrait être la meilleure option pour propager des rhizomes indemnes de maladie, car la sécheresse freine avec succès le développement bactérien, désintégrant le pathosystème. c'est-à-dire éviter une humidité élevée, qui est l'une des conditions idéales pour la croissance bactérienne. La plantation précoce en saison sèche en utilisant l'irrigation est une pratique rentable et facilement applicable pour lutter contre la flétrissure bactérienne du gingembre.

Mots Clés: Plantation sèche précoce, irrigation, Zingiber officinale

\section{INTRODUCTION}

Ginger (Zingiber officinale Rosc.) is one of the important export crops in sub-Saharan Africa (SSA), grown for its underground aromatic rhizome (Sharma et al., 2010). It is a cash crop for many smallholder growers in SSA (Sah et al., 2017). The rhizome is valued throughout the world as a spice of flavouring agent, for its two major classes of constituents, namely, essential oils and oleoresins (Baladin et al. 1998). In every Ethiopian kitchen, ginger rhizome is used for preparation of pepper powder and Ethiopian stew (wat, Amharic) (Mergia, 2019). In Ethiopia, ginger grows predominantly in South Nations, Nationalities and Peoples Regional State (SNNPRS), accounting for $99 \%$ of the total yearly production of the crop (Endrias and Asfaw, 2011).

Prior to the outbreak of Ginger Bacterial Wilt, which occurred in 2012 in Ethiopia, the country was earning about 11 to 22 million US dollars annual incomes from its export (ITC, 2010). A sharp drop in production and supply, however, followed because of a sudden outbreak of a destructive Ginger Bacterial Wilt (GBW). In the same year of disease outbreak, an estimated incidence of $80-100 \%$, which gave rise to up to $90-100 \%$ crop loss was registered in the fields (Habtewold et al., 2015; Tariku et al., 2016). Total yield loss caused by Ralistonia solanacearum was also reported in other countries (Zhang et al., 2001). Following its outbreak, GBW in Ethiopia infected all ginger varieties within two years 
(2012-2013), irrespective of genotypes and geographic locations (Tariku et al., 2016).

Management of bacterial wilt is very difficult as it has wide host range, long survival rates in the soil, spreads in many ways, survives in vegetation as latent infection and due to the presence of genetically diverse strains of the bacterium (European Union, 2003; American Psychopathological Society, 2005). Ralistonia exists systemically in seed rhizomes both as an active and latent infection (Kelman et al., 1994), which makes its control more difficult. In addition, GBW is a complex disease infecting ginger through all phases of the production cycle, yet no effective control measure has been designed so far (Yang and Guo, 2010).

According to Habtewold et al. (2015), heavy successive rainfall (monthly average $287.9 \mathrm{~mm}$ ) or high humidity (>90\%) and warm soil temperature (maximum average 27.8 $\left.{ }^{\circ} \mathrm{C}\right)$, which prevail occasionally but simultaneously from June to August, aggravate its virulence. Such weather conditions are ideal for multiplication of bacterial cells at faster rate, resulting in high bacterial inoculum loads per host rhizome cells; eventually resulting in significant yield losses. Understanding ideal conditions for the development of bacterial wilt is crucial to designing an efficient disease control strategy. One of the successful strategies could be disintegration of the pathosystem or avoidance of some components of the disease triangle across successive growth stages, in this case, high humidity ( $>90 \%)$. Fragmentation of the disease triangle (avoidance of high humidity) could be successfully achieved through early planting of the ginger seed rhizomes in dry season (November to January) using irrigation to retard the development of the pathogen, to produce healthy or disease free rhizomes.

Early planting in the dry season under a rain-fed condition is an age-old practice in the ginger belt of Ethiopia (Endrias and Asfaw, 2011). However, no report is available on the use of irrigation for ginger cultivation in the country, on one hand, and exploitation of its role in the management of GBW disease, on the other. Early planting in dry season, using irrigation would be relatively simple; thus, it is easily applicable at smallholder's level to manage the disease. The objective of this study was to evaluate the effect of moisture sources, plant spacing, and nitrogen fertiliser on rhizome yield and yield attributes of latently infected ginger seed rhizomes.

\section{MATERIALS AND METHODS}

Study area. The study was carried out from March, 2017 to December, 2018 in Himbecho rural Kebele of Boloso-Sorie District (Wolayita, Ethiopia). The site is located at an altitude 1708 meter above sea level; latitude $7^{\circ} 8^{11} 16^{\prime \prime}$ and longitude $37^{\circ} 41^{18}$. The area is characterised by bimodal rainfall, with the short rainy season running from March to May, while long/main rainy season extends from June to September. The dry season, which ranges from October to February in the ginger belt of Ethiopia, occasionally receives erratic rainfall. The life cycle of ginger as a biennial crop covers both growing seasons and part of the dry months receiving the year-round total volume of the rainfall. The total annual rainfall for the experimental year 2017 was $1658 \mathrm{~mm}$ and the minimum and maximum average temperatures recorded were 14.3 and $27.2{ }^{\circ} \mathrm{C}$, respectively. Rainfall and temperatures recorded in 2018 in the same order as preceding statement were $1710 \mathrm{~mm}$ and 23.7 and $13.3{ }^{\circ} \mathrm{C}$. Onset of the rains was too late (April) in 2017 for ginger production in the study area. Weather data were obtained from the nearby meteorological station, located in Areka Agricultural Research Centre. The site was characterised by silty loam soil.

Experimental design, planting materials and agronomy. The experiment was laid out in a $2 \times 2 \times 3$ factorial arrangement in randomised complete block design (RCBD, with three replications. Treatments were two 
levels of moisture sources (irrigation and rains as the control), two levels of plant spacing (40 cm x $15 \mathrm{~cm}$ and $40 \mathrm{~cm} \times 30 \mathrm{~cm}$ ) and three rates of $\mathrm{N}\left(0,46\right.$ and $\left.92 \mathrm{~kg} \mathrm{ha}^{-1}\right)$. Planting in rows at $40 \mathrm{~cm}$ apart from each other, was prepared manually, maintaining the recommended planting depth of $10 \mathrm{~cm}$. Ginger planting for either of the rain-fed or irrigated conditions was done early in dry season (January) in both years. Application of water using conventional furrow irrigation (each row was irrigated) was done twice a week, until the onset of the rains; and continued in cases of rain shortage. Early planting for irrigated and rain-fed plots was done on the same date. Ginger planting in rain-fed condition during early dry season, is a common farmers practice in the study area.

Early dry season in Ginger Belt of Ethiopia, where the study site is located (administrative zones of Kembata-Tembaro, Wolayita, and Dawro) extends from November to January. Latently infected seed rhizomes of the popular ginger cultivar, Volvo, was used as a source of seed rhizome, since all ginger genotypes across the whole country were latently infected with Ginger Bacterial Wilt disease, Ralistonia solanacearum bio var. 3. Cultivar Volvo is characterised by yellow cortex colour, 2-3 prominent roots and high preference in fresh ginger markets. The size of the propagules or seed rhizomes used for planting was in the range of $2.5-5.0 \mathrm{~cm}$.

The total plot size used in this experiment was $2 \mathrm{~m} \times 1.5 \mathrm{~m}$, with the net plot size of 1.2 $\mathrm{m} \times 1.5 \mathrm{~m}$. Three of the middle rows of each plot were considered for data collection. Fifty per cent of the recommended rate of urea (50 $\mathrm{kg}$ and $100 \mathrm{~kg} \mathrm{ha}^{-1}$ depending on the levels of the treatment) was applied after $50 \%$ of emergence and the remaining 50\% was applied one month after emergence. However, the full dose of $200 \mathrm{~kg} \mathrm{ha}^{-1} \mathrm{NPS}(\mathrm{N}=38, \mathrm{P}=33$, and $\mathrm{S}=14$ ) fertiliser was applied at planting time in all plots, except for the control treatment. All experimental plots were kept weed free by hoeing.
Data collection and analysis. Stand count at harvest and agronomic data on number of buds per rhizome, number of rhizome per plant, rhizome size $(\mathrm{cm})$, weight of rhizome (g) and total fresh rhizome yield $\left(\mathrm{t} \mathrm{ha}^{-1}\right)$ were recorded during harvesting. Data were analysed using Statistical Analysis System (SAS) package (version 9.0 of SAS Institute Inc. (SAS, 2014), with adjusted Least Significance Difference (LSD) at 5\% probability level.

\section{RESULTS AND DISCUSSION}

Ginger rhizome yield. Fresh ginger rhizome yield from latently infected seed rhizomes as influenced by different levels of moisture sources, plant spacing and nitrogen rates are shown in Table 1. Rhizome yield was significantly $(\mathrm{P}<0.01)$ affected by the main effects of moisture sources and plant spacing in 2017. However, no interaction effect was observed to influence rhizome yield between any of the factors involved. The yield recorded in rain-fed and irrigated plots ranged between 8.2 and $36.3 \mathrm{t} \mathrm{ha}^{-1}$, respectively, which is in line with the findings reported by Islam et al. (2015), where cultivating ginger with irrigation in dry period gave higher rhizome yield. Vadivel et al. (2006) also noted higher ginger rhizome yield under better water management condition. Nonetheless, no report is available so far on planting ginger early in dry season using irrigation purposely to manage Ginger Bacterial Wilt disease.

Higher rhizome yield variation recorded due to differences in moisture sources clearly indicated that planting using irrigation early in dry season, which involves disintegration of Ginger Bacterial Wilt pathosystem (disease triangle); or avoiding high humidity, would be efficacious to manage Ginger Bacterial Wilt disease. It is believed that early planting with consistently available soil moisture right from planting helps the crop to exploit the total annual precipitation received across the 
TABLE 1. Ginger fresh rhizome mean yield $\left(\mathrm{t} \mathrm{ha}^{-1}\right)$ as influenced by moisture sources, planting spaces and nitrogen rates in 2017 and 2018 in Ethiopia

\begin{tabular}{|c|c|c|c|c|c|c|c|c|c|c|}
\hline \multirow[t]{5}{*}{$\mathrm{N}$ rate $\left(\mathrm{kg} \mathrm{ha}^{-1}\right)$} & \multicolumn{5}{|c|}{2017} & \multicolumn{5}{|c|}{2018} \\
\hline & \multicolumn{4}{|c|}{ Moisture Sources (MS) } & Mean & \multicolumn{4}{|c|}{ Moisture Sources (MS) } & Mean \\
\hline & \multicolumn{2}{|c|}{ Rainfall } & \multicolumn{2}{|c|}{ Irrigation } & & \multicolumn{2}{|c|}{ Rainfall } & \multicolumn{2}{|c|}{ Irrigation } & \\
\hline & \multicolumn{5}{|c|}{-- Planting spaces (PS) $(\mathrm{cm})---$} & \multicolumn{4}{|c|}{ - - Planting spaces (PS) (cm) ---} & \\
\hline & PS1 & PS2 & PS1 & PS2 & & PS1 & PS2 & PS1 & PS2 & \\
\hline 0 & $6.5 \mathrm{~d}$ & $5.1 d$ & $41.1 \mathrm{a}$ & $27.0 \mathrm{cb}$ & 19.9 & 36.7 & 24.4 & 25.5 & 32.2 & 29.7 \\
\hline 46 & $10.5 \mathrm{~cd}$ & $7.3 \mathrm{~cd}$ & $42.3 \mathrm{a}$ & $33.0 \mathrm{ab}$ & 23.3 & 33.3 & 24.4 & 36.9 & 26.7 & 30.3 \\
\hline 92 & $12.3 \mathrm{~cd}$ & $7.7 \mathrm{~cd}$ & $39.4 a$ & $35.0 \mathrm{a}$ & 23.6 & 38.2 & 26.7 & 33.3 & 34.4 & 33.2 \\
\hline $\mathrm{CV}(\%)$ & 23.6 & & & & & - & & & & \\
\hline $\mathrm{LSD}_{0.05}$ & 13.0 & & & & & NS & & & & \\
\hline MS & 8.2 & & 36.3 & & & 30.6 & & 31.5 & & \\
\hline PS & 25.4 & 19.2 & & & & 34.0 & 28.1 & & & \\
\hline
\end{tabular}


growing season, which might improve uptake and utilisation of available nutrients.

In the successive experimental years (2017-2018), disease symptoms were not detected. The major focus of the present study was on quantitative evaluation of ginger rhizome yield and yield attributes in both sources of moisture. The highest yield obtained from irrigated plots $\left(36.3 \mathrm{t} \mathrm{ha}^{-1}\right)$ demonstrated the typical characteristics of healthy rhizomes, which would not have been possible in plants with pathogen epidemic. Basically, the uptake of water after manifestation of Ginger Bacterial Wilt disease symptom (wilting) would fully cease in diseased plants following the blockage of the xylem conduits through accumulation of bacterial inoculum in the collar areas. Consequently, rhizome bulking would shortly ceases because of termination of translocation of the photosynthate to the sink, which in turn leads to poor rhizome bulking. Poorly bulked rhizomes exhibit remarkably reduced dry matter content.

Prior to the outbreak of the Ginger Bacterial Wilt disease, per cent of drying recovery (storage moisture being maintained at 7-10\%) was $22-24 \%$ depending on the harvest age and cultivar type (Endrias and Asfaw, 2011), which later declined to the level below $10 \%$ just after the outbreak of the disease in the country. However, mean drying recovery of about $20 \%$ (data not shown) was recorded for apparently healthy rhizomes generated from latently infected propagules planted early in dry season using irrigation. Figure $1 \mathrm{~A}$ and B illustrate physical appearance of apparently healthy and heavily damaged daughter rhizomes harvested from latently infected mother seed rhizome with Ginger Bacterial Wilt disease pathogen.

Ginger Bacterial Wilt disease would not be a problem for ginger production, particularly in areas of adequate irrigation water since early planted ginger in dry season using irrigation matures ahead (June-August) of the onset of the ideal conditions that favor pathogen development and the resultant daughter rhizome would be apparently healthy or could be disease free. The load of bacterial inoculum in apparently healthy daughter rhizome (physically huge) is supposed to be minimal. But it should be taken into consideration that Ralistonia solanacearum becomes virulent if conditions that trigger its development are there.

Figure 2 illustrates field performance of ginger planted early in dry season (January) under irrigated and rain-fed conditions, using

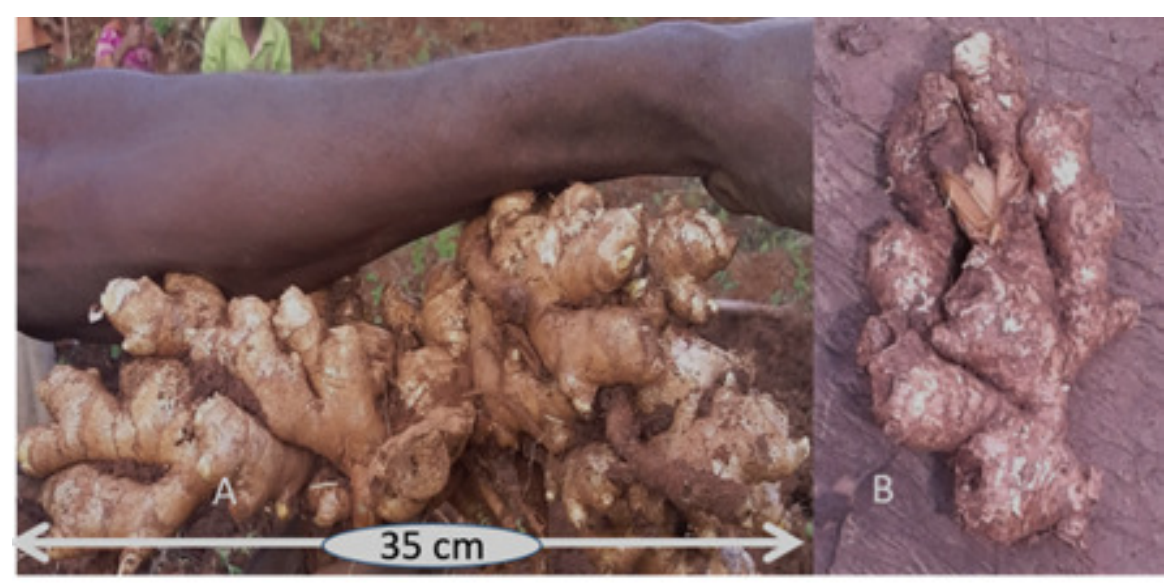

Figure 1. Physical appearance of apparently healthy (A) and heavily damaged (B) daughter rhizomes harvested from latently infected mother seed rhizomes in Ethiopia. Both rhizomes (A and B), were obtained from latently infected rhizomes planted in early prolonged dry season. 


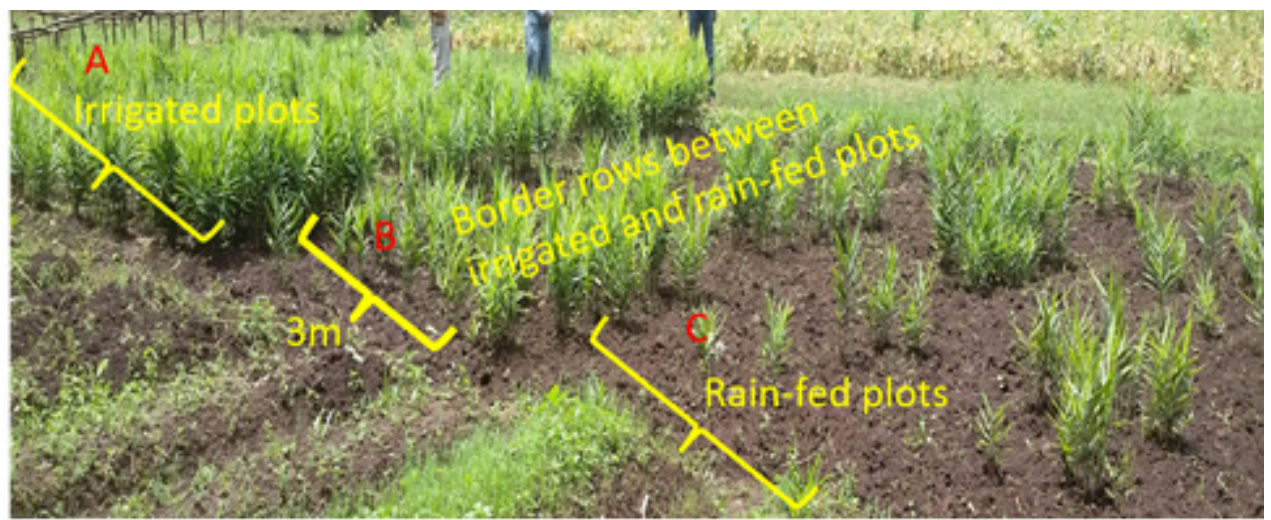

Figure 2. Field performance of ginger planted early in dry season under irrigation (A) and rain-fed (C) using latently infected seed rhizomes in 2017 in Ethiopia.

latently infected seed rhizomes. Early planting using irrigation maintained uniformity in plant growth (Fig. 2A). During the first year (2017) of the experiment, the onset of the rain was too late in the season (April) and plots planted earlier (January) on dry soil under a rain-fed condition could not emerge until the onset of the rain (April). Thus, most of the propagules were prone to desiccation, as a result of osmotic dehydration, which followed late emergence and sparsely populated crop stand, which resulted in drying of most propagules (Fig. 2C). But it should be noted that rain-fed planting would not always result in propagule drying. Drying could be prevented by planting the propagule deep in the soil (more than 10 $\mathrm{cm}$ ) with the recommended planting depth being 5-10 $\mathrm{cm}$ (Jansen, 1981) and by pulverising the seedbed finely to minimise escape of residual soil moisture. Deep planting is essential to minimise osmotic dehydration of small rhizome setts, when ginger is planted early in extended dry season (Kandiannan, 1996).

From another stand point, the juvenile stage of the crop, owing to late emergence, would have had a high chance of overlapping with ideal environmental conditions (warm temperature $\left(>27.8^{\circ} \mathrm{C}\right)$ and high rainfall $(>288$ $\mathrm{mm}$ of monthly average) that trigger disease development (Habtewold et al., 2015); which occasionally occurs through June to August.
However, early planting in dry season using supplemental irrigation guarantees early emergence, followed by early maturity of the crop ahead of the possible time of the onset of the ideal weather conditions for bacterial development. In other words, once the crop reaches its full maturity, the effect of Ralistonia on ginger rhizome yield would be insignificant. According to Islam et al. (2015), as long as rainfall is unpredictable in rain-fed agriculture, taking advantage of any available irrigation systems could reduce the risks of crop loss due to long dry spell and to harvest better quality rhizomes. On the contrary, there are some low-altitude (below 800 m.a.s.l.) pocket areas in south-western part of Southern Ethiopia (e.g. Bebeqa, and Tepi), which are characterised by almost a year-round humid and warm weather conditions. In such environments, revitalisation of ginger production, particularly with latently infected rhizomes seems to be hardly possible.

In the second experimental year (2018), when the onset of the Belg rainfall was early in the season (short dry season), variations in moisture sources (irrigation and rainfall) did not show significant difference in crop performance (Fig. 3) and rhizome yield (Table 1). In 2018, though the onset of the rain was earlier in the season (mid-January) and the chance for the juvenile stage to overlap with the ideal conditions for the disease development 


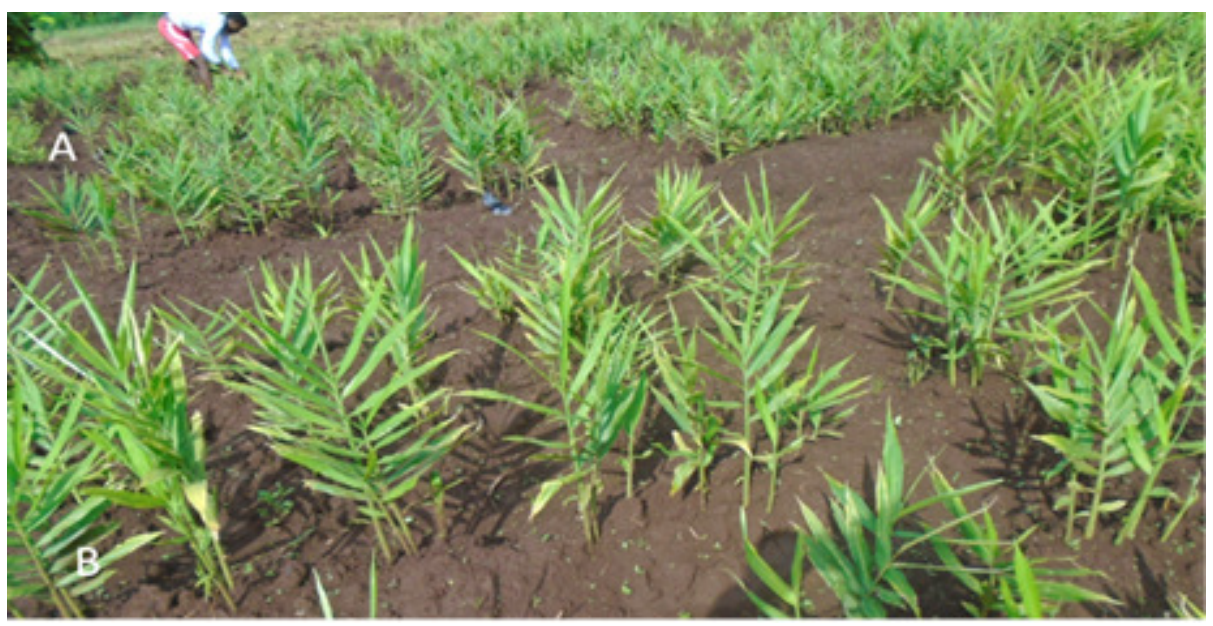

Figure 3. Field performance of ginger planted early in dry season under rain-fed condition (A) and with irrigation (B) using latently infected seed rhizomes in 2018 in Ethiopia. No border blocks were used since the irrigated blocks were located at the bottom of the rain-fed blocks.

was higher, disease symptom was not observed, indicating that Ralistonia solanacearum biovar 3 (Tariku et al., 2016) is a sporadic disease in terms of bacterial development in mother seed rhizomes/ propagules and disease symptom appearance in daughter plants. This shows that Ralistonia solanacearum becomes virulent when the weather conditions satisfy (synergetic effect of more than $90 \%$ relative humidity and $28^{\circ} \mathrm{C}$ soil temperature) its fast rate of multiplication (Habtewold et al., 2015) in latently infected mother propagules.

In this experiment, plant spacing significantly $(\mathrm{P}<0.05)$ influenced ginger rhizome yield in both experimental years (Table 1). Spacing at $40 \mathrm{~cm} \times 15 \mathrm{~cm}$ gave $25.4 \mathrm{t}$ $\mathrm{ha}^{-1}$ and spacing at $40 \mathrm{~cm} \times 30 \mathrm{~cm}$ attained $19.2 \mathrm{t} \mathrm{ha}^{-1}$ fresh rhizome yield in 2017. In $2018,40 \mathrm{~cm}$ x $30 \mathrm{~cm}$ plant spacing in reverse gave significantly higher yield of $34.0 \mathrm{t} \mathrm{ha}^{-1}$ than spacing at $40 \mathrm{~cm} \times 15 \mathrm{~cm}$, which provided $28.1 \mathrm{t} \mathrm{ha}^{-1}$. Here, reversibility of the significance levels between the results of the two treatments (SP1 and SP2) across both years could be associated with insufficiency of the soil moisture in rain-fed plots in 2017, owing to late onset of the rain, for normal physiological functioning of the plants. However, the choice of planting spaces in ginger culture, when dealing with ginger Bacterial Wilt disease, must be given particular attention, in view of avoiding ideal conditions for bacterial development (high humidity and high temperature), rather than making recommendations solely based on significance level. On the other hand, when it comes to the contribution of spacing to the management of GBW, wider planting space could be more desirable as narrow spaces showed a tendency to develop humid and warm conditions when the crop's canopy fully covers the ground. Wider planting space was found to facilitate the process of application of furrow irrigation and other farm operations on one hand, and improved air circulation within the plant population, thereby to retard bacterial activity on the other.

Analysis of variance showed that different levels of nitrogen could not influence ginger rhizome yield significantly during both years (Table 1). This is in contrast with the finding reported by Egbuchua and Enujeke (2013), in which increasing levels of $\mathrm{N}$ significantly affected yield of ginger rhizome in a typical rainforest zone, Nigeria. In the current 
experiment, the reasons that different levels of $\mathrm{N}$ in irrigated plots could not affect ginger rhizome yield significantly might be attributed to the wash away or leaching down of the $\mathrm{N}$ from the crop's rhizosphere associated with the silty loam nature of the soil as a result of frequently applied (twice a week) furrowbased irrigation. In line with this, Arjun (2009), in an irrigation systems study, recognised that nutrient uptake was significantly the lowest under surface irrigation system. In the present study, the purpose of irrigation was simply to keep the soil moisture nearly at a field capacity to ensure normal growth of the crop and to popularise the irrigation practice to farmers in view of managing Ginger Bacterial Wilt disease.

Stand count and number of buds rhizome

${ }^{1}$ hill $^{-1}$. Table 2 illustrates that stand count at harvest was significantly influenced $(\mathrm{P}<0.05)$ by a three-way interaction effect of moisture sources, planting spaces and nitrogen fertiliser. Similarly, number of buds plant ${ }^{-1}$ hill $^{-1}$ was significantly $(\mathrm{P}=0.001)$ influenced by the interaction effect of moisture sources and planting spaces. Planting ginger bacterial wilt infected seed rhizomes early in dry season with irrigation increased number of actively growing buds (Table 2).

Number of rhizomes per mother propagule and size of rhizomes. Number of rhizomes per mother propagule was significantly influenced $(\mathrm{P}<0.001)$ by a three-way interaction effect of moisture sources, planting spaces and nitrogen fertiliser (Table 3). Ginger plants that received adequate amount of water through irrigation, accompanied with other appropriate agronomic packages right from planting, gave two or more rhizomes per mother propagule (Fig. 4). Such a phenomenon may be termed as double or multiple palmation. Thus, such a change of scenario of formation of two or more rhizomes per single mother seed rhizome could guarantee more propagules per planting materials for ginger propagation on one hand and high productivity of the crop per unit area for commercial production on the other.

The size of rhizomes also varied significantly $(\mathrm{P}<0.01)$ as the interaction effect of moisture sources and planting spaces, with a mean rhizome size of $24.4 \mathrm{~cm}$ being recorded with irrigation; as opposed to $15.6 \mathrm{~cm}$ attained in a rain-fed condition. In line with this, an earlier study reported by Girma and Kinde (2008), indicated the average length of the rhizome produced in a rain-fed condition prior to the outbreak of GBW disease in southwestern Ethiopia was $9.45 \mathrm{~cm}$. Some daughter rhizomes obtained from latently infected mother rhizomes/propagules planted early in dry season with irrigation also resulted in rhizomes measuring as long as over $30 \mathrm{~cm}$ (Fig. 5), which confirmed that the bacterial inoculum load per cell in a daughter rhizome system was negligible or absent. Furthermore, rhizome size was affected significantly $(\mathrm{P}<0.01)$ as a result of a single effect of nitrogen fertiliser (Table 3 ).

Weights of daughter rhizome and propagule. Results confirmed that weights of propagule were significantly $(\mathrm{P}<0.05)$ affected by the three-way interaction effect of moisture sources, planting spaces and nitrogen fertiliser (Table 4). However, both yield attributes, i.e., weight of daughter rhizome and propagule were influenced by the interaction effect of moisture sources and planting spaces.

Ginger plants from latently infected mother cut pieces, supplemented with furrow irrigation from planting to the onset of the Belg rain, gave propagules weighing $33.8 \mathrm{~g}$ as opposed to $30.1 \mathrm{~g}$ obtained from rain-fed condition (Table 4) in the same season. Large propagules which have been reported to have an influence on the sprouting rate, early growth and development of the crop (Lawal, 2016) resulted from a massive food reserve to enhance rapid development of the newly emerging plants, which eventually ends up with high rhizome yield (Asafa and Akambi, 2018). In Ethiopia, most farmers prefer planting 
TABLE 2. Results of combined analysis of yield attributes (SCH and NB) of latently infected ginger cultivar Volvo (2017 and 2018) grown in Ethiopia

\begin{tabular}{|c|c|c|c|c|c|c|c|c|c|c|}
\hline \multirow[t]{5}{*}{$\mathrm{N}$ rate $\left(\mathrm{kg} \mathrm{ha}^{-1}\right)$} & \multicolumn{4}{|c|}{ Stand count at harvest $(\mathrm{SCH})$} & Mean & \multicolumn{4}{|c|}{ Number of buds rhizome ${ }^{-1}(\mathrm{NB})$} & \multirow[t]{5}{*}{ Mean } \\
\hline & \multicolumn{4}{|c|}{$--ー-$ Moisture Sources $-ー-ー$} & & -- & \multicolumn{3}{|c|}{ Moisture Sources $--ー-ー$} & \\
\hline & Rainfall & \multicolumn{3}{|c|}{ Irrigation } & & \multicolumn{2}{|c|}{ Rainfall } & \multicolumn{2}{|c|}{ Irrigation } & \\
\hline & --- & \multicolumn{2}{|c|}{ Plant spacing $(\mathrm{cm})$} & \multirow{2}{*}{$\begin{array}{l}-- \\
\text { PS2 }\end{array}$} & & \multicolumn{2}{|c|}{ - Plant-spacing $(\mathrm{cm})$} & \multicolumn{2}{|c|}{$-\quad-$} & \\
\hline & PS1 & PS2 & PS1 & & & PS1 & PS2 & PS1 & PS2 & \\
\hline 0 & $9.7 \mathrm{e}$ & $17.3 \mathrm{c}$ & $13.3 \mathrm{~d}$ & $25.8 \mathrm{a}$ & 16.5 & $10.7 f$ & $14.2 \mathrm{cde}$ & $14.5 \mathrm{~cd}$ & $16.5 b$ & 14.0 \\
\hline 46 & $9.5 \mathrm{e}$ & $20.8 b$ & $13.3 \mathrm{~d}$ & $26.8 \mathrm{a}$ & 17.6 & $11.5 \mathrm{ef}$ & $15.2 \mathrm{bcd}$ & $14.3 \mathrm{~cd}$ & $22.5 \mathrm{a}$ & 15.9 \\
\hline 92 & $9.0 \mathrm{e}$ & $18.0 \mathrm{c}$ & $13.3 \mathrm{~d}$ & $22.8 b$ & 15.8 & $13.3 \mathrm{def}$ & $14.8 \mathrm{~cd}$ & $14.7 \mathrm{~b}$ & $22.8 \mathrm{a}$ & 16.4 \\
\hline $\mathrm{CV}(\%)$ & 13.6 & & & & & 14.7 & & & & \\
\hline $\mathrm{LSD}_{0.05}$ & 1.07 & & & & & 6.1 & & & & \\
\hline \multicolumn{11}{|l|}{ Mean } \\
\hline MS & 14.1 & & 19.2 & & & 13.3 & & 18.1 & & \\
\hline PS & 11.4 & 21.9 & & & & 13.2 & 15.0 & & & . \\
\hline
\end{tabular}

$\mathrm{N}=$ nitrogen, $\mathrm{PS} 1=40 \times 15, \mathrm{PS} 2=40 \times 30, \mathrm{CV}=$ Coefficient of variation, $\mathrm{LSD}=$ least significant difference. Mean values with the same letter (s) in the column are not significantly different $(\mathrm{P}<0.05)$ by LSD test 
TABLE 3. Results of combined analysis of yield attributes, number of rhizomes per mother propagule (RN) and rhizome size (RS) of apparently healthy ginger cultivar Volvo (2017 and 2018)

\begin{tabular}{|c|c|c|c|c|c|c|c|c|c|c|}
\hline \multirow[t]{5}{*}{$\mathrm{N}$ rate $\left(\mathrm{kg}^{-1}\right)$} & \multicolumn{4}{|c|}{ Number of rhizomes per mother propagule } & Mean & \multicolumn{4}{|c|}{ Rhizome size (RS) (cm) } & \multirow[t]{5}{*}{ Mean } \\
\hline & \multicolumn{4}{|c|}{---- Moisture source (MS) ----} & & - & \multicolumn{3}{|c|}{ Moisture source $(\mathrm{MS}) \quad---$} & \\
\hline & \multicolumn{2}{|c|}{ Rainfall } & \multicolumn{2}{|c|}{ Irrigation } & & \multicolumn{2}{|c|}{ Rainfall } & \multicolumn{2}{|c|}{ Irrigation } & \\
\hline & \multicolumn{3}{|c|}{ - - - Plant spacing (PS) $(\mathrm{cm})$} & \multirow{2}{*}{$\begin{array}{l}-- \\
\text { PS2 }\end{array}$} & & \multicolumn{3}{|c|}{ - - - Plant spacing (PS) (cm) } & \multirow{2}{*}{$\begin{array}{c}--- \\
\text { PS2 }\end{array}$} & \\
\hline & PS1 & PS2 & PS1 & & & PS1 & PS2 & PS1 & & \\
\hline 0 & $1.0 \mathrm{e}$ & $1.7 \mathrm{bcd}$ & $1.7 \mathrm{bcd}$ & $2.1 \mathrm{ab}$ & 1.6 & $15.0 \mathrm{c}$ & $15.1 \mathrm{c}$ & $21.1 b$ & $26.2 \mathrm{a}$ & 19.4 \\
\hline 46 & $1.0 \mathrm{e}$ & $1.0 \mathrm{e}$ & $2.1 \mathrm{ab}$ & $1.3 \mathrm{cde}$ & 1.4 & $12.6 \mathrm{~d}$ & $13.3 \mathrm{c}$ & $20.3 b$ & $27.0 \mathrm{a}$ & 18.3 \\
\hline 92 & $1.0 \mathrm{e}$ & $1.3 \mathrm{~cd}$ & $1.8 \mathrm{abc}$ & $2.3 \mathrm{a}$ & 1.6 & $16.1 \mathrm{c}$ & $17.3 \mathrm{c}$ & $22.5 b$ & $29.0 \mathrm{a}$ & 21.2 \\
\hline $\mathrm{CV}(\%)$ & 35.1 & & & & & 12.6 & & & & \\
\hline $\mathrm{LSD}_{0.05}$ & 0.25 & & & & & 1.18 & & & & \\
\hline \multicolumn{11}{|l|}{ Mean } \\
\hline MS & 1.2 & & 1.9 & & & 15.6 & & 24.4 & & \\
\hline PS & 1.4 & 1.6 & & & & 17.9 & 21.3 & & & \\
\hline
\end{tabular}


larger propagules than using cut- pieces of the recommended size $(2.5-5.0 \mathrm{~cm}$ ) (Girma and Kinde (2008) (Fig. 6 ). Farmers believe that large propagules planted earlier in dry season are less prone to osmotic dehydration or desiccation in case of late onset of the rainfall in the season. It is widely accepted that unlike smaller propagules, larger propagules do not decompose or decay after giving rise to new plants, until harvesting stage of respective

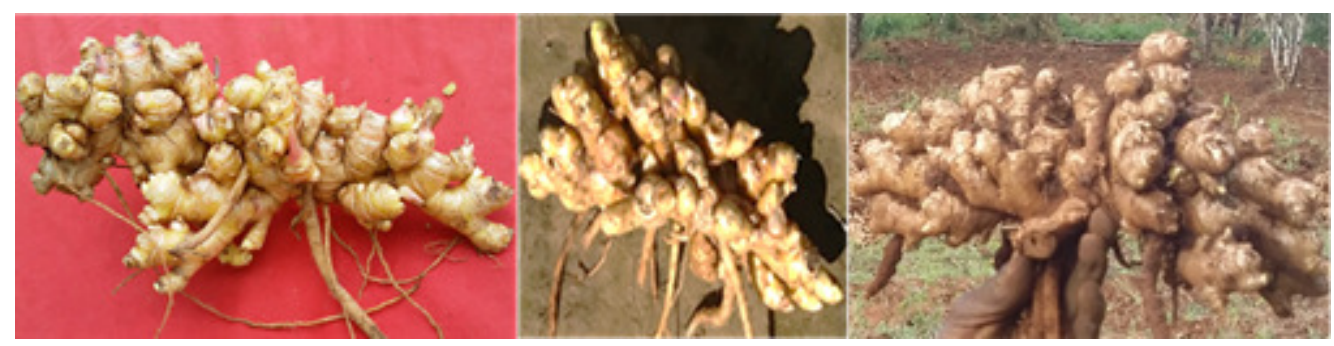

Figure 4. One or more rhizomes per mother propagule formed because of the receipt of early and continuous soil moisture during prolonged dry season: single (left); double (middle) and multiple (right) rhizome.

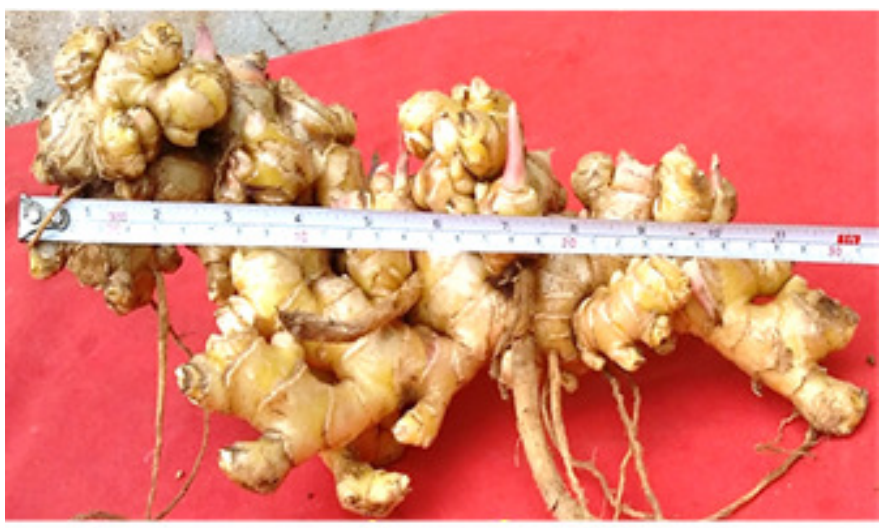

Figure 5. Ginger rhizome obtained from latently infected seed rhizome planted early in dry season with irrigation.
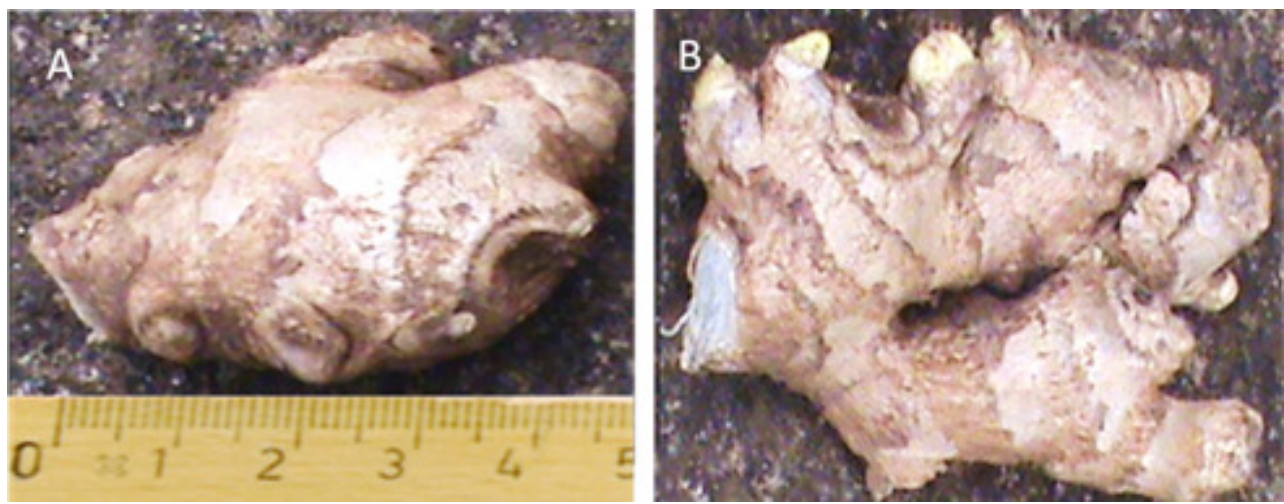

Figure 6. Recommended size of ginger rhizome propagule (A) and propagule of most farmers preference (B) with extra number of active growing buds. 
TABLE 4. Results of combined analysis of yield attributes (RW and PW) obtained by planting infected ginger cultivar Volvo (2017 and 2018 )

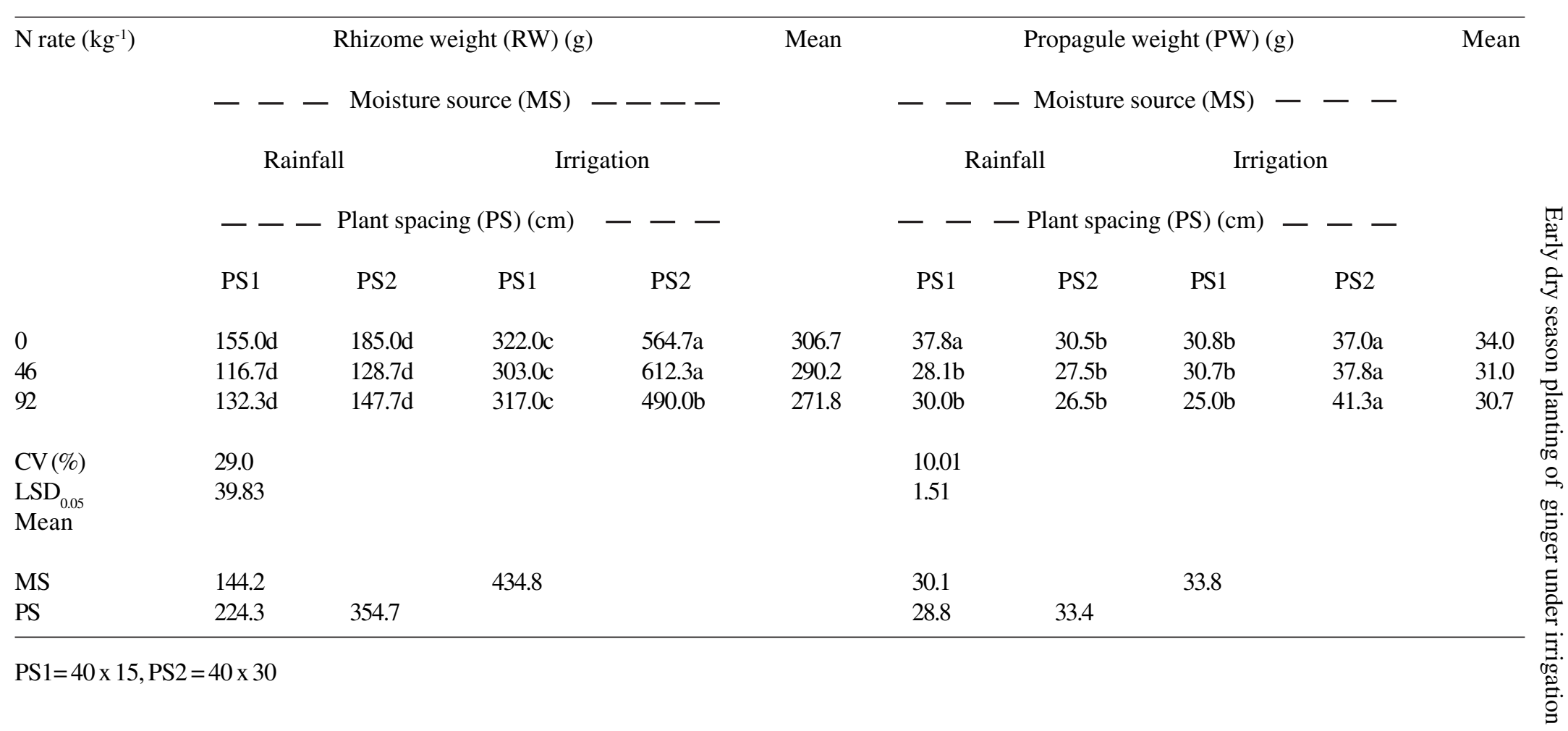


daughter rhizomes (Okwuowulu, 1988). Thus, farmers can get additional agronomic or economic benefits by taking advantage of reharvesting of them (Endrias andAsfaw, 2011).

According to Kandiannan et al. (1996), mother seed rhizomes are removed from the daughter rhizomes during a certain crop growth stage, without significantly affecting yield of the daughter rhizomes. In this practice, it was reported that a mean of $58 \%$ of seed ginger from smaller old setts and $86 \%$ from larger old setts could be recovered. By this method, farmers can regain 60 to $70 \%$ of the seed cost. Rahman et al. (2009) observed that removal of mother rhizome is believed to give proper space to the developing/daughter rhizome.

Irrigated plots gave mean rhizome weight of $434.8 \mathrm{~g}$ as opposed to $144.2 \mathrm{~g}$ obtained in a rain-fed condition (Table 4). Similarly, plant spacint at $40 \mathrm{~cm} \times 15 \mathrm{~cm}$ provided a mean rhizome weight of 224.3 as opposed to 354.7 g obtained from planting space of $40 \mathrm{~cm}$ x 30 $\mathrm{cm}$. Weight of some individual rhizomes obtained from latently infected propagules planted early in dry season using irrigation was comparable with the weight of non-infected large rhizomes produced earlier than the disease outbreak (Fig. 7).

In Ethiopia, fresh ginger production and supply have been concentrated in a few months of the year (December to March). Early dry planting under a rain-fed condition is commonly practiced by farmers mainly from January through March, expecting the onset of the Belg rain in March. Ginger planting in the ginger belt of Ethiopia, has never been practiced from May to November. Consequently, supply of fresh ginger in the country was concentrated in the months of December to April. However, from the result of the current experiment, it could be concluded that restriction of planting period and product supply to certain months of the year could be changed nearly to a year-round production and supply by making use of irrigation in areas where dependable moisture sources are available. This implies that either smallholders or commercial producers can generate continuous income and premium prices, which might arise from the relation of low supply and high demand of the product during off season. Planting ginger using irrigation was also found to be a good opportunity to source ginger planting material (seed rhizome) during off season to make planting at any possible time. Another interesting observation with irrigation was the possibility of expanding ginger culture into areas where ginger has never been produced. Figure 8 illustrates field performance of ginger planted with irrigation in an area where it was never produced.
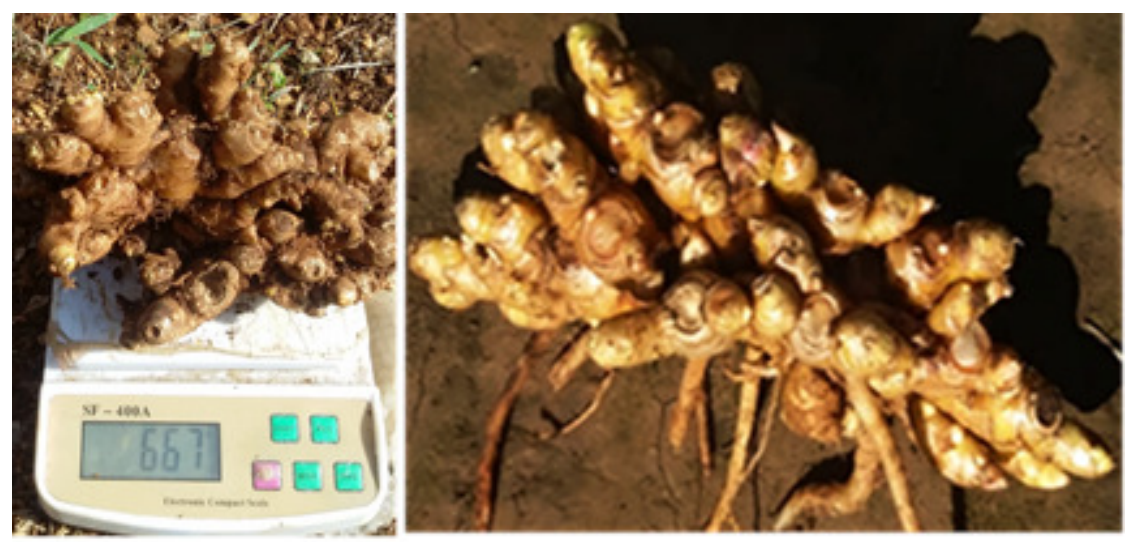

Figure 7. Apparently healthy ginger daughter rhizomes obtained from Ralistonia-infected ginger seed rhizomes planted early in dry season using irrigation in Ethiopia. 


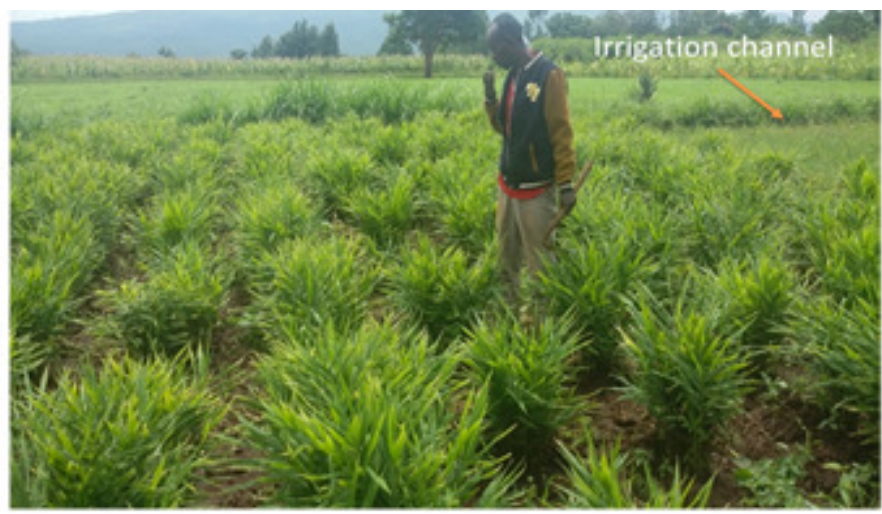

Figure 8. Ginger planted early in dry season with irrigation in Ethiopia where its production was not known previously.

\section{CONCLUSION}

This study has clearly indicated the possibility of producing high rhizome yield from early planted Ralistonia-infected mother seed rhizome in dry season using supplementary furrow irrigation. Rationally thinking, there is no chance of development of bacterial inoculum to the level of virulence in dry season once the disease triangle is disintegrated or the patho-system is disturbed. Disintegration of the GBW disease triangle, in this case, removing high humidity (>90\%) could be the best option to control the disease. The ginger rhizome yield obtained from latently infected and healthy mother seed rhizomes from similar unit area is comparable if early planting in dry period using irrigation is practiced. Early planting, taking advantage of any available irrigation systems during dry season could reduce threat of yield loss due to long dry spell or pathogenic reaction. Apart from controlling GBW disease, planting latently infected ginger early in dry season using furrow irrigation could improve ginger rhizome yield and yield attributes.

In this activity, nitrogen levels could not influence ginger rhizome yield significantly, may be attributed to leaching and wash away of nitrogen from the crop's rhizosphere in a silty loan loam soil. Using wider row spacing of 50 to $60 \mathrm{~cm}$ in furrow irrigation system could better facilitate water supplying, ventilation under crop's canopy or other farm operations either in manual or mechanical ginger production systems but the cost-benefit analysis should be conducted in order to evaluate the effect of plant spacing on the yield and pathogenic reaction. Laboratory analysis is also required to test if daughter rhizomes generated from latently infected mother propagules are disease free or still latently infected with GBW pathogen.

\section{ACKNOWLEDGMENT}

This research was supported financially by FARM AFRICA- Ethiopia and Southern Agricultural Research Institute (SARI). The authors are grateful to Dr. Deribe Gemiyo, and Abebe Kirub for pre-reviewing of the manuscript. We also acknowledge Dr. Waga Mazengia for his assistance in data analysis.

\section{REFERENCES}

APS (American Phytopathological Society). 2005. Bacterial wilt diseases and the Ralstonia solanacearum species complex. APS Press, American Phytopathological Society. St. Paul, Minnesota, USA.

Arjun, S.D. 2009. Effect of irrigation systems and integrated nutrient management on growth, yield and quality of ginger 
(Zingiber officinale Rosc.). PhD dissertation. Mahatma Phule Krishi Vidyapeeth, Rahuri-413722 Agricultural College, India.

Asafa, R.F. and Akambi, W.B. 2018. Growth and rhizome yield of ginger (Zingiber officinale R.) as Influenced by Propagule Size and Nitrogen Levels in Ogbomoso, Southwestern Nigeria. International Letters of Natural Sciences 67:35-45.

Baladin, D.A, Headley, O, Chang, L.Y and, Mcgaw, D.R. 1998. High pressure liquid chromatographic analysis of the main pungent principles of solar dried West IndianGinger. Rentable Energy 13(14):531536.

Egbuchua, C.N. and Enujeke, E.C. 2013. Growth and yield responses of ginger (Zingiber officinale) to three sources of organic manures in a typical rainforest zone, Nigeria. Journal of Horticulture and Forestry 5(7):109-114.

Endrias, G and Asfaw, K. 2011. Production, processing and marketing of ginger in Southern Ethiopia. Journal of Horticulture and Forestry 3(7):207-213.

EU (European Union). 2003. Ralstonia solanacearum: EPPO quarantine pest. Prepared by CABI and EPPO under the contract 90/399003.

Girma, H.M, Digafie, T. and Edossa, E. 2008. Spices research achievements, revised ed., Ethiopian Institute of Agricultural Research, Addis-Ababa, Ethiopia.

Habetewold, K., Bekelle, K., Kasahun, S. and Tariku, H. 2015. Prevalence of bacterial wilt of ginger (Z. officinale) caused by Ralstonia solancearum (Smith) in Ethiopia. International Journal of Research Studies in Agricultural Sciences (IJRSAS) 1:14-22.

International Trade Center (ITC). 2010. Spice sub-sector strategy for Ethiopia, by spice sub-sector strategy coordinating committee with collaboration of International Trade Center (ITC). February, 2010.
Islam, M.A., Rahim, M.A. and Iqbal, T.M.T. 2015. Effect of irrigation and mulching on growth and yield of ginger. Bangladesh Agronomic Journal 18(1):27-36.

Jansen, P.C.M. 1981. Spices, condiments and medicinal plants in Ethiopia, their taxonomy and agricultural significance. Wageningen PUDOC. pp. 1-132.

Kandiannan, K., Sivaraman, K., Thankamani, C.K. and Peter, K.V. 1996. Agronomy of ginger (Zingiber officinale Rosc). Journal of Spices and Aromatic Crops 5(1):1-27.

Kelman, A., Hartman, G.L. and Hayward, A.C. 1994. Introduction. pp. 1-7. In: Bacterial wilt: the disease and its causative agent, Pseudomonas solanacearum. Hayward, A.C, Hartman, G.L, editors. Wallingford: CAB International.

Merga, J, Habtamu, T, and Eshetu, D. 2018. Integrated management of bacterial wilt (Ralstonia solanacearum) of ginger (Zingiber officinale) in Southwestern Ethiopia. MSc. Thesis. Haramaya University, Haramaya, Ethiopia.

Okwuowulu, P.A. 1988. A parent sett recycling edible ginger production in South Eastern Nigeria. Tropical Science 28:177-184.

Sah, D.; Heisnam, P.; Mahato, N.K. and Pandey, A.K. 2017. Weed management in ginger (Zingiber officinale Roscoe) through integrated approaches. International Journal of Current Microbiology and Applied Sciences 6(10): 1839-1845.

SAS Institute Inc., 2014. SAS/STAT ${ }^{\mathrm{TM}}$ user's guide, version 9.3. Cary, N.C. SAS Institute Inc.

Sharma, B.R., Dutta, S., Roy, S., Debnath, A. and Roy, M.D. 2010. The effect of soil physicochemical properties on rhizome rot and wilt disease complex incidence of ginger under hill agro climatic region of West Bengal. Journal of Plant Pathology. 26:198-202.

Tariku, H., Kassahun, S. and Gezahegne, G. 2016. First report of ginger (Zingiber 
officinale) bacterial wilt disease in Ethiopia. Research Journal of Agriculture and Forestry Sciences 4(4):5-9.

Vadivel, V., Senthikumaran, P. and Dhusoodan, K.J. 2006. Problems and prospective of ginger production and export. Spice India. 19(4):38-42.

Yang, W. and Guo, J. 2010. A screening strategy of bacterial biocontrol agents towards Ralstonia Wilt of Ginger. Phytopathology 100:S141.

Zhang, G.G., Zhu, F.H., Zheng, J., Wang, J. and Ding, A. 2001. Study on the pathogen of the ginger wilt disease in Shandong. Journal of Shandong Agricultural University 32(4):418-22. 